\title{
FRESH LEAVES OF ORA-PRO-NÓBIS IN CAKES PREPARED FROM COMMERCIAL PRE-MIXTURE
}

\author{
INCLUSÃO DE FOLHAS FRESCAS DE ORA-PRO-NÓBIS EM BOLOS \\ ELABORADOS A PARTIR DE PRÉ-MISTURA COMERCIAL
}

\author{
Lidiane ROSA ${ }^{1}$; Carla Regina Amorim dos Anjos QUEIROZ²; Claudia Maria Tomás MELO² \\ 1. Tecnóloga em Alimentos, ex-aluna do Instituto Federal do Triângulo Mineiro. lidianeteixeira@yahoo.com.br; 2. Professora do \\ Instituto Federal do Triângulo Mineiro, Campus Uberlândia, MG, Brasil;
}

\begin{abstract}
Establishing good eating habits in childhood is quite important for proper growth and development. Vegetables such as the ora-pro-nóbis (an unconventional vegetable, known in English speaking countries as Barbados Goosenberry, scientific name Pereskia aculeata Miller) have leaves that are rich in proteins, fibers and minerals, such as iron. These nutrients can contribute to improving child food products. In order to improve the nutritional value of commercial chocolate cake premixes, in natura ora-pro-nóbis leaves were added at ratios of 0 (standard), 10, 20,30 and 40\% leaf weight per batter weight, which were covered with chocolate icing. Moisture, ashes, lipids, proteins, crude fiber, carbohydrates and total caloric content (TCC) were analyzed in the elaborated formulations. The cakes with green leaves of ora-pro-nóbis are technologically viable up to $40 \%$ of leaf inclusion. The results showed a significant increase in water retention, crude fiber content and decrease in total caloric content (TCC) in cakes to which ora-pro-nóbis leaves were added. Lipid content was not affected by treatments.
\end{abstract}

KEYWORDS: Bakery foods. Food products for children. Pereskia aculeata Miller. Unconventional vegetables.

\section{INTRODUCTION}

Time spent preparing healthy meals has became scarce due to the increased quantity of mothers working outside the home. This way, people have been choosing more and more ready-toeat food, providing their children with diets low in essential nutrients for growth and development. Improper and frequent consumption of processed foods can compromise health in childhood and adulthood in addition to reducing the consumption of fresh food (AQUINO; PHILIPPI, 2002). Such observations are reinforced by Mello, Barros and Morais (2016), who checked food consumption and adequacy in Brazilian children from 2003 to 2013, and showed that their feeding presents low consumption of meat, fruits and vegetables; high consumption of cow's milk, early intake of fried food, sweets, soft drinks and salt.

According to Carvalho et al. (2015), the food consumption of Brazilian infants is characterized by high frequencies of inadequacy of micronutrients intake, such as iron, vitamin A and zinc. Both excess and deficiencies were verified. Protein-energy malnutrition, in the other hand, has decreased in last decades, giving raise to overweight and obesity phenomenon (MELLO; BARROS; MORAIS, 2016).
Despite all evidence pointing to poor nutrition as the cause of various diseases, each day more children consume substantial amounts of food with fat excess and low fiber (GALLAGHER et al., 2003), mainly because of processed food consumption.

Pereskia aculeata Miller is a native cactus that can be found in Brazil and is called 'ora-pronóbis' (OPN) (Figure 1). It has large amounts of ash (approximately 16\% in dry basis) and is therefore a good source of calcium, magnesium, iron and zinc. Its content of dietary fiber is considered high (39\%) and its protein (28\% - dry basis) is similar to other green edible leaves (KINUPP; BARROS, 2008; TAKEIT; ANTONIO; MOTTA, 2009). This plant has been pursued by food and drug industries because of its characteristics, aside from being regarded as a complementary leafy vegetable in periods when there is a lack of others (SOUZA et al., 2009).

Alternative sources of nutrients, such as unconventional vegetables, can provide nutrients at a low cost, especially when derived from home plantings (BRASIL, 2010). A varied diet can be fed by adding those vegetables in food formulations such as pasta, bread and cookies (MARTINEVSKI et al., 2013; SILVA et al., 2014; RAMOS; QUEIROZ, 2019). The green leaves of many plant species are sources of protein; however, their use in 
food may be impaired by extraction cost, large volume of leaves, palatability and processing. Plant proteins generally have lower costs, thus becoming a good unconventional source for food preparation (GAVA, 2004).

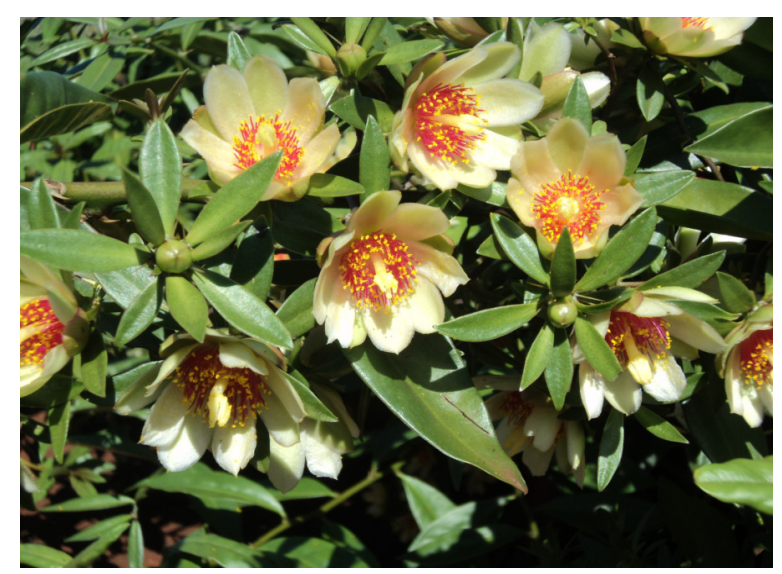

Figure 1. Ora-pro-nóbis plant at breeding stage with leaves and open flowers. This plant is under cultivation in Federal Institute of Triângulo Mineiro. Source: Authors.

Ora-pro-nóbis leaves have excellent amino acid profile. The content of this plant's essential amino acids is enough to supply the FAO/WHO (Food and Agriculture Organization of United Nations/ World Health Organization) suggested requirements for children from 2 to 5 years old. Hence, the use of OPN leaves in food products should be considered (TAKEIT; ANTONIO; MOTTA, 2009).

Some studies have been carried out to enhance the nutritional value of food, e.g. homemade cake supplementation, which has great acceptability from children to the elderly. Moscato et al. (2004) developed cake formulations at varied proportions of yacon flour, which increased the total fiber content.

We aimed to test different proportions of OPN fresh leaves added to commercial pre-mixtures for cakes, possibly improving its nutritional value by analyzing their chemical compositions and caloric values.

\section{MATERIAL AND METHODS}

Ora-pro-nóbis (OPN) leaves were obtained from the nursery at the Federal Institute of Triângulo Mineiro (IFTM), Uberlândia Campus MG, Brazil. The leaves, harvested from developed branches were cleaned in water, sanitized in sodium hypochlorite $100 \mathrm{pmm}$ solution for 15 minutes and rinsed in running water and freshly applied to the preparation of the cake batters. Commercial premixtures and other ingredients were purchased at a local market. The ingredients bought had the same brand and batch (pre-mixture, eggs margarine $80 \%$ fat and whole milk); all ingredients were in valid period of consumption.

The cakes were made using a pre-mixture (pre-formulated batter) of chocolate flavor. During preparation, we added fresh OPN leaves at the following ratios: 0 (control), 10, 20, 30 and $40 \%$ fresh leaf mass per batter weight. All measurements were taken using semi-analytical scale (Gehaka).

The leaves were beaten in a blender along with eggs (3), milk $(150 \mathrm{~mL})$ and margarine $(60 \mathrm{~g})$ following the instructions given on the pre-mixture packaging, and then combined with the batter. The cakes were baked as recommended by the manufacturer and covered with chocolate icing.

The chocolate icing was traditional Brazilian brigadeiro, which was done over medium heat, combining cocoa -3 tablespoons, margarine 3 tablespoons and condensed milk - $395 \mathrm{~g}$, under stirring, until thickened, about 10 minutes.

For the control cake (OPN free; 0\%) the same procedure was followed except for the inclusion of the leaves. For each ratio, five cakes were produced. These replicates underwent physicochemical analyses, which were performed twice.

The chemical compositions (moisture, ash, protein, lipid and crude fiber) of all formulations were analyzed at IFTM's physical chemistry laboratory, following methodology proposed by Instituto Adolfo Lutz (IAL, 2008), except for carbohydrates, which were determined by the difference between $100 \%$ and the sum of water, ashes, proteins, lipids and fibers (CARVALHO et al., 2002). The total caloric content (TCC) was calculated based on the data of lipids, carbohydrates 
and proteins on a wet basis, as shown in Equation 1 (CARVALHO et al., 2002).

$$
\begin{gathered}
\mathrm{TCC}\left(\mathrm{kcal} 100 \mathrm{~g}^{-1}\right)=(\% \mathrm{P} \times 4.0)+(\% \mathrm{~L} \times 9.0)+(\% \\
\mathrm{C} \times 4.0) \\
\text { Equation } 1
\end{gathered}
$$

TCC: total calories

P: protein

L: lipid

C: carbohydrate

Data underwent variance analysis

(ANOVA) at a 5\% and $1 \%$ significance level.

Subsequently, means were compared by the Tukey's test through ASSISTAT software (SILVA; AZEVEDO, 2002).

\section{RESULTS AND DISCUSSION}

Table 1 shows the results of physicochemical analysis. They revealed a considerable influence of OPN addition on ash content $(\mathrm{p}<0.05)$, moisture, protein, crude fiber and carbohydrates $(\mathrm{p}<0.01)$. However, lipid content had no influence on OPN in the assessed ratios.

Considering that fresh leaves contain an average water content of $90 \%$, the treatments corresponded to an average addition of 1 to $4 \%$ dry leaves.

Table 1. Average results ( \pm standard deviation) of moisture $(\mathrm{M})$, ashes $(\mathrm{A})$, lipids $(\mathrm{L})$, proteins $(\mathrm{P})$, crude fiber

\begin{tabular}{|c|c|c|c|c|c|c|}
\hline \multirow{3}{*}{$\begin{array}{l}\text { OPN } \\
(\%)\end{array}$} & \multicolumn{6}{|c|}{ Chemical composition } \\
\hline & $\mathrm{M}^{* *}$ & $\mathrm{~A}^{*}$ & $\mathrm{~L}^{\mathrm{NS}}$ & $\mathrm{P}^{* *}$ & $\mathrm{CF}^{* *}$ & $\mathrm{C}^{* *}$ \\
\hline & \multicolumn{6}{|c|}{------------------------------------\% m/m------------------------------ } \\
\hline $\mathbf{0}$ & $22.4 \pm 1.5 \mathrm{~d}$ & $2.1 \pm 0.3 \mathrm{ab}$ & $9.5 \pm 1.9 \mathrm{a}$ & $9.0 \pm 0.6 \mathrm{a}$ & $2.8 \pm 1.0 \mathrm{~b}$ & $55.1 \pm 2.9 \mathrm{a}$ \\
\hline 10 & $26.0 \pm 1.9 \mathrm{~cd}$ & $1.9 \pm 0.1 \mathrm{~b}$ & $8.6 \pm 1.4 \mathrm{a}$ & $8.5 \pm 0.6 \mathrm{ab}$ & $6.6 \pm 1.3 \mathrm{a}$ & $49.3 \pm 1.5 b$ \\
\hline 20 & $28.9 \pm 1.7 \mathrm{bc}$ & $2.1 \pm 0.1 \mathrm{ab}$ & $8.2 \pm 2.0 \mathrm{a}$ & $7.6 \pm 0.2 \mathrm{c}$ & $5.7 \pm 1.9 \mathrm{a}$ & $48.2 \pm 2.3 \mathrm{bc}$ \\
\hline 30 & $33.6 \pm 1.3 \mathrm{a}$ & $2.2 \pm 0.1 \mathrm{a}$ & $7.5 \pm 1.5 \mathrm{a}$ & $7.3 \pm 0.2 \mathrm{c}$ & $4.9 \pm 1.0 \mathrm{ab}$ & $45.2 \pm 2.5 b c$ \\
\hline 40 & $32.5 \pm 3.9 \mathrm{ab}$ & $2.2 \pm 0.1 \mathrm{a}$ & $8.9 \pm 2.0 \mathrm{a}$ & $8.1 \pm 0.3 b c$ & $4.6 \pm 1.5 \mathrm{ab}$ & $43.7 \pm 3.0 \mathrm{c}$ \\
\hline C.V. $(\%)$ & 7.9 & 7.3 & 20.7 & 5.3 & 28.5 & 5.3 \\
\hline
\end{tabular}
$(\mathrm{CF})$ and carbohydrates $(\mathrm{C})$ in cakes made with the addition of fresh ora-pro-nóbis (OPN) leaves, in a wet basis.

${ }^{* *},{ }^{*}$ Significant data by the $\mathrm{F}$ test of variance analysis at $1 \%$ and $5 \%$ probability respectively; ${ }^{\text {NS }}$ non-significant data. Means followed by different letters in the column differ statistically at 5\% probability by the Tukey's test; CV represents the coefficient of variation (\%).

Cake batter moisture increased from the $20 \%$ ratio of leaf addition. This result indicates production of moister cakes, which are generally more valued; however, an increased moisture level may enhance microbial activity. As stated by Esteller and Lannes (2005), who evaluated bakery products, an excess of humidity can leave the final product sticky and chewy. Despite the higher water content, we did not observe any of those characteristics in the cakes with OPN leaf addition between 20 and $40 \%$. The increase in moisture content in the formulations with 30 and $40 \%$ leaves averaged $47.5 \%$ compared to the control. This was expected because of the increase of leaves, which have high levels of water.

Moisture levels of this study reached values close to those found in custom or specially-made cakes such as with addition of yacon flour (near
38\%) (MOSCATTO; PRUDÊNCIO-FERREIRA; HAULY, 2004), oat fractions (between 26.4 and $32.6 \%$ ) (GUTKOSKI et al., 2009), and whey (from 21.3 to $22.6 \%$ ) (ZAVAREZE et al., 2010).

The ash content varied from 1.9 to $2.2 \%$, being higher in cakes prepared with addition of 30 and $40 \%$ leaves compared to those with $10 \%$. Yet the control (without OPN) did not differ from formulations with 10 and $20 \%$. The increase in ash content is helpful to reach the daily mineral intake recommendation. In cakes prepared with addition of oats, the ashes content ranged between 1.8 and 2.9\% (GUTKOSKI et al., 2009); and with yacon addition, the variation was from 1.6 to $1.9 \%$ (MOSCATTO; PRUDÊNCIO-FERREIRA; HAULY, 2004). Therefore, the ash content observed in this study are within the range found in other formulations. 
Lipid content was not changed by adding OPN in the cakes. We observed an average of $8.5 \%$ of lipids. Thus, OPN addition had no influence on the lipid composition of the elaborated cakes, assuming the maintenance of the other ingredients, the quantity of OPN leaves was not enough to decrease lipid content. This result is explained considering the presence of the other ingredients carrying lipids (milk, margarine, and batter) which were present in higher quantities.

Regarding protein content, no differences among treatments (20, 30 and 40\%) were observed, The control was similar to addition of $10 \%$ leaves, both showed higher contents if compared to $20 \%$ and $30 \%$ leaves added. That could have been caused by the use of non-standardized eggs in cake formulation and milk, which could have concealed differences in the quantity of protein among treatments, since eggs and milk have a substantial protein content. Furthermore, in nature leaves have about $90 \%$ water. The range of protein added to the cakes from the OPN leaves is from $0.25 \%$ to $1 \%$, respectively from $10 \%$ to $40 \%$ of fresh leaves (considering the average of $25 \%$ protein in leaves on dry basis).

The crude fiber content grew abruptly as leaf content increased. Comparing with the control, we observed that a $10 \%$ increase in the amount of leaves made crude fiber content rise to $135.7 \%$. According to the results, all treatments with leaf addition led to an increase in crude fiber content and do not differ from each other. We obtained a product with more than twice the fiber content of the control by adding $10 \%$ and $20 \%$ OPN leaves. This improvement is of great importance because even a small quantity of leaves was enough to produce a cake with a higher fiber content, which is considered healthier than low fiber content food.
According to the national normative resolution n. 54 from November 12, 2012 (BRASIL, 2012), a product is high in dietary fiber (DF) when it has at least $6 \mathrm{~g}$ of fiber per $100 \mathrm{~g}$ (solids), $100 \mathrm{~mL}$ (liquids), or $5 \mathrm{~g}$ per serving of ready-cooked meals; it can also be considered as a fiber source when it has $3 \mathrm{~g}$ of fiber per $100 \mathrm{~g}$ of product (solids), 100 $\mathrm{mL}$ (liquids) or $2.5 \mathrm{~g}$ of fiber per serving. Although we have determined the crude fiber content $(\mathrm{CF})$, and there is no direct conversion from $\mathrm{CF}$ to $\mathrm{DF}$, we want to emphasize that in all formulations the quantity of fiber per cake serving portion, at an equivalent to $60 \mathrm{~g}$ for unfilled cakes (RDC n. 359; BRASIL, 2003), was greater than the minimum required to be called as a source of fiber.

Furthermore, a $60 \mathrm{~g}$ piece of cake (a serving portion) with $10 \%$ OPN leaves within its formulation would meet a daily fiber requirement of about $26.4 \%$ for children between 4 to 8 years old, and about $25.3 \%$ for girls between 9 to 18 years old, as estimated by the Institute of Medicine of the National Academies (IOM, 2005).

Based on values of dietary reference intake (DRI) and protein established by the Institute of Medicine (IOM, 2005), each $60 \mathrm{~g}$ of cake in any formulation or standard would meet on average $39 \%$ of DRI for kids between 1 and 3 years old, $27 \%$ for those between 4 and 6 and $15 \%$ for children from 7 to 10 (BRASIL, 2005, RDC 269). Nevertheless, cakes are not considered a source of protein, since a cake serving $(60 \mathrm{~g})$ has only $6 \mathrm{~g}$ of protein (BRASIL, 2012, RDC n. 54).

Total calorie content (TCC) decreased by $14.3 \%$, on average, in the formulations when including 20 to $40 \%$ OPN leaves (Table 2). However, there were no differences among treatments with leaves. Therefore, we can state that from a $10 \%$ leaf addition on, there is a reduction of about $15 \%$ in the TCC.

Table 2. Mean values ( \pm standard deviation) of total calorie content (TCC) and dry extract in cakes made with addition of fresh ora-pro-nóbis leaves.

\begin{tabular}{lll}
\hline \% LEAVES & TCC $^{* * *}$ & DRY EXTRACT $^{* * *}$ \\
\cline { 2 - 3 }$(\%)$ & ${\mathrm{kcal} 100 \mathrm{~g}^{-1}}$ & \% \\
\hline 0 & $337.8 \pm 12.7 \mathrm{a}$ & $77.6 \pm 1.5 \mathrm{a}$ \\
10 & $305.5 \pm 11.5 \mathrm{ab}$ & $74.0 \pm 1.9 \mathrm{ab}$ \\
20 & $294.3 \pm 19.6 \mathrm{~b}$ & $71.1 \pm 1.7 \mathrm{bc}$ \\
30 & $275.0 \pm 10.3 \mathrm{~b}$ & $66.4 \pm 1.3 \mathrm{~d}$ \\
40 & $299.5 \pm 34.9 \mathrm{~b}$ & $67.5 \pm 3.9 \mathrm{~cd}$ \\
\hline
\end{tabular}

${ }^{* *}$ Significant data by the $\mathrm{F}$ test of variance analysis at $1 \%$ probability. Means followed by different letters in the column differ statistically at $5 \%$ probability by the Tukey's test. 
Dry extract percent and total calories had significant differences $(\mathrm{p}<0.01)$ by adding OPN leaves. Since they are complementary, moisture content increased with dry extract decrease by adding fresh leaves.

Paula et al. (2016) when developing research on cake processing with the Pereskia aculeata Mill. plant found that it can be included in daily diets, as it proves to be a rich protein food, besides being low cost. According to the results of the sensory analysis, the authors concluded that the addition of Pereskia aculeata leaf in cake influenced the sensory profile and cake coloration, however, the elaborated samples were accepted in the cake acceptance test, both for $50 \mathrm{~g}$ as for $100 \mathrm{~g}$ of green leaves of Pereskia aculeata. Based on the sensory tests, they found that the advantage of preparing a $100 \mathrm{~g}$ sample is that it has a higher protein percentage, which has several health benefits.

\section{CONCLUSIONS}

The cakes with green leaves of ora-pronóbis are technologically viable up to $40 \%$ of leaf inclusion.

Cakes with addition of fresh ora-pro-nóbis leaves have high content of crude fiber and proteins for all formulations, besides of reduction of total calories.

The improvement in cake nutritional characteristics indicates that it could be an alternative to a better consumption of cakes, compared with compared to cakes without the enhanced use of OPN.

\section{ACKNOWLEDGEMENTS}

The authors thank FAPEMIG for their financial support for project development and IFTM-Campus Uberlândia for the structure of laboratories and reagents for the chemical analyzes performed.

RESUMO: O estabelecimento de uma boa alimentação na infância é de suma importância para o crescimento e desenvolvimento adequados. Vegetais como a ora-pro-nóbis (hortaliça não convencional) que possuem em suas folhas proteínas, fibras e minerais como o ferro, podem contribuir para melhorar a alimentação infantil. Com objetivo de melhorar o valor nutricional de pré-misturas comerciais de bolo, foram adicionadas folhas de ora-pro-nóbis in natura na proporção de 0 (padrão), 10, 20, 30 e 40\% de folhas em relação a massa de sólidos pré-formulada para elaboração do bolo de sabor chocolate, com cobertura de chocolate tipo brigadeiro. Foram realizadas análises de umidade, cinzas, lipídeos, proteínas, fibra bruta e determinados os teores de carboidratos e valor calórico total (VCT) nas formulações elaboradas. Os bolos elaborados com folhas de ora-pro-nóbis in natura são viáveis do ponto de vista tecnológico, até $40 \%$ de inclusão de folhas. Os resultados revelaram um aumento significativo na retenção de água, no teor de fibra bruta e diminuição do valor calórico total (VCT) nos bolos adicionados de folhas de ora-pro-nóbis. Não houve influência dos tratamentos sobre o conteúdo de lipídeos.

PALAVRAS-CHAVE: Alimentação infantil. Hortaliça não convencional. Produto de panificação. Pereskia aculeata Miller.

\section{REFERENCES}

AQUINO, R. C. de; PHILIPPI, S. T. Consumo infantil de alimentos industrializados e renda familiar na cidade de São Paulo. Revista Saúde Pública [online], v. 36, n. 6, p. 655-660, 2002. https://doi.org/10.1590/S003489102002000700001

BRASIL. Resolução RDC n 359, de 23 de dezembro de 2003. Aprova Regulamento Técnico de Porções de Alimentos Embalados para Fins de Rotulagem Nutricional. Brasília, 2003.

BRASIL. Resolução RDC n 269 , de 22 de setembro de 2005. Regulamento técnico sobre a ingestão diária recomendada (IDR) de proteína, vitaminas e minerais. Brasília, 2005. 
BRASIL. Ministério da Agricultura, Pecuária e Abastecimento. Manual de hortaliças não-convencionais / Ministério da Agricultura, Pecuária e Abastecimento. Secretaria de Desenvolvimento Agropecuário e Cooperativismo. - Brasília: Mapa/ACS, 2010. 92 p.

BRASIL. Resolução da Diretoria Colegiada $n^{\circ}$ 54, de 12 de Novembro de 2012. Dispõe sobre o Regulamento Técnico sobre Informação Nutricional Complementar. Brasília, 2012.

CARVALHO, H. H.; JONG, E. V. de; BELlÓ, R. M. SOUZA, R. B. de; TERRA, M. F. Alimentos: Métodos Físicos e Químicos de Análise. Porto Alegre: UFRGS, 2002. 180p.

CARVALHO, C. A. de; FONSÊCA, P. C. de A.; PRIORE, S. E.; FRANCESCHINI, S. do C. C.; NOVAES, J. F. de Food consumption and nutritional adequacy in Brazilian children: a systematic review. Revista Paulista de Pediatria. v. 33, n. 2, p. 211-221, 2015

ESTELLER, M. S.; LANNES, S. C. da S. Identidade e qualidade de produtos panificados. Food Science and Technology, v. 25, n. 4, p. 802-806, 2005. https://doi.org/10.1016/S2359-3482(15)30053-1

GALLAGHER. E.; O'BRIEN, C.M.; SCANNELL, A.G.M.; ARENDT, E.K. Use of response surface methodology to produce functional short dough biscuits. Journal of Food Engineering, v. 56, n. 2-3, p. 269271, 2003. https://doi.org/10.1016/S0260-8774(02)00265-0

GAVA, A. J. Princípios de tecnologia de alimentos. São Paulo: Nobel, 2004. 284p.

GUTKOSKI, L. C., TEIXEIRA, D. M. de F., DURIGON, A., GANZER, A. G., BERTOLINI, T. E., COLLA, L. M. Influência dos teores de aveia e de gordura nas características tecnológicas e funcionais de bolos. Food Science and Technology, v. 29, n. 2, p. 254-261, 2009. https://doi.org/10.1590/S0101-20612009000200003

IAL (INSTITUTO ADOLFO LUTZ). Métodos físico-químicos para análise de alimentos. 4 ed. São Paulo: IAL, 2008. 1018p

INSTITUTE OF MEDICINE OF THE NATIONAL ACADEMIES (IOM). Dietary Reference Intakes for Energy, for Energy, Carbohydrate, Fiber, Fat, Fatty Acids, Cholesterol, Protein and Amino Acids. Whashington, 2005. 1357 p.

KINUPP, V. F.; BARROS, I. B. I. D. Teores de proteínas e minerais de espécies nativas, potenciais hortaliças e frutas. Food Science and Technology, v. 857, p. 846, 2008. https://doi.org/10.1590/S0101-

20612008000400013

MARTINEVSKI, C. S.; OLIVEIRA DE, V.R.; RIOS, A.O.; FLORES, S.H.; VENZKE, J.G. Utilização de bertalha (Andredera cordifolia (Ten.) Steenis) e ora-pro-nóbis (Pereskia aculeata Mill.) na elaboração de pães. Alimentos e Nutrição, Araraquara, v. 24, n. 3, p. 1-6, jul./set. 2013.

MELLO, C. S.; BARROS, K. V.; MORAIS, M. B. de Brazilian infant and preschool children feeding: literature review. Jornal de Pediatria. v. 92, n. 5, p. 451-463, 2016. https://doi.org/10.1016/j.jpedp.2016.06.009

MOSCATTO, J. A.; PRUDÊNCIO-FERREIRA, S. H.; HAULY, M. C. O. Farinha de yacon e inulina como ingredientes na formulação de bolo de chocolate. Food Science and Technology, v. 24, n. 4, p. 634-640, 2004. https://doi.org/10.1590/S0101-20612004000400026

PAULA de, M. C.; OLIVEIRA de, R. B.; FELIPE, D. F.; MAGRINE, I. C. O.; Sartor, C. F. P. Processamento de bolo com a planta Pereskia aculeata MILL. (Ora-pro-nóbis). Revista Brasileira de Produtos

Agroindustriais, Campina Grande, v.18, n.2, p.167-174, 2016. https://doi.org/10.15871/1517-

8595/rbpa.v18n2p167-174 
RAMOS, R. de O.; QUEIROZ, C. R. A. A. Desenvolvimento e caracterização física de pão de cebola com adição de ora-pro-nóbis. In: Júlio César Ribeiro; Carlos Antônio dos Santos. (Org.). A Face Multidisciplinar das Ciências Agrárias 2. 1ed. Ponta Grossa, Paraná: Atena Editora, 2019. p. 163-172. https://doi.org/10.22533/at.ed.02019290716

SILVA, F. de A. S.; AZEVEDO, C. A. V. de. Versão do programa computacional Assistat para o sistema operacional Windows. Revista Brasileira de Produtos Agroindustriais, v.4, n.1, p. 71-78, 2002. https://doi.org/10.15871/1517-8595/rbpa.v4n1p71-78

SILVA, D. O. da; PRIMIO, E. M. di; BOTELHO, F. T.; GULARTE, M. A. Valor nutritivo e análise sensorial de pão de sal adicionado de Pereskia aculeata. Demetra: Alimentação, Nutrição \& Saúde, v. 9, n. 4, p. 10271040, 2014. https://doi.org/10.12957/demetra.2014.11119

SOUZA, M. R. M.; CORREA, E. J. A.; GUIMARÃES, G.; PEREIRA, P. R.G. O Potencial do Ora-pro-nóbis na Diversificação da Produção Agrícola Familiar. Revista Brasileira de Agroecologia, v. 4, n. 2, 2009.

TAKEIT, C. Y.; ANTONIO, G. C.; MOTTA, E. M. P.; COLARES-QUEIROZ, F. P.; PARK, K. J. Nutritive evaluation of a non-convencional leafy vegetable (Pereskia aculeata Miller). International Journal of Food Science and Technology, v. 1, n. 60, p. 148-160, 2009. https://doi.org/10.1080/09637480802534509

ZAVAREZE, E. da R.; MORAES, K. S.; SALAS-MELLADO, M. de Las M. Qualidade tecnológica e sensorial de bolos elaborados com soro de leite. Food Science and Technology, v. 30, n. 1, p. 100-105, 2010.

https://doi.org/10.1590/S0101-20612010000100015 